\title{
Craniocerebral trauma in motorcyclists: relation of helmet use and trauma severity
}

Traumatismos craniocerebrais em motociclistas:
relação do uso do capacete e gravidade

Viviane da Cunha Dutra ${ }^{1}$

Rita Catalina Aquino Caregnato ${ }^{1,2}$

Maria Renita Burg Figueiredo ${ }^{1}$

Daniela da Silva Schneider ${ }^{1}$

Keywords

Accidents, traffic; Emergency medical services; Brain injuries; Motorcycle

Descritores

Acidentes de trânsito; Serviços médicos de emergência; Traumatismos craniocerebrais; Motocicletas

Submitted

July 3, 2014

Accepted

July 29, 2014
Corresponding author

Daniela da Silva Schneider

Farroupilha Avenue, 8001, Canoas, RS,

Brazil. Zip Code: 92425-900

daniela@schneider.inf.br

DOI

http://dx.doi.org/10.1590/1982-

0194201400079

\section{Abstract}

Objective: Relating the helmet use with the severity of craniocerebral trauma in injured motorcyclists treated at a trauma hospital.

Methods: A cross-sectional, retrospective study. The study population consisted of 188 records of service to injured motorcyclists in a four-month period. The Glasgow Coma Scale was used to characterize the severity of trauma.

Results: The profile is $84.6 \%$ of males and $55.3 \%$ aged between 18 and 29 years. Regarding the use of helmet at the time of the accident, $51.6 \%$ used, $6.4 \%$ did not use, $17.6 \%$ used it inappropriately, and there were no records in $24.5 \%$. Among the $51.6 \%$ of motorcyclists who used the protective gear, $86.6 \%$ had mild craniocerebral trauma, $12.4 \%$ had moderate, and $1 \%$ severe. The most serious injuries occurred in motorcyclists in which there were no records on helmet use.

Conclusion: The motorcyclists who used the helmet, had mild craniocerebral trauma in $44.7 \%$ of cases, moderate trauma in $6.4 \%$, and severe trauma in $0.5 \%$. Victims without records of the situation of helmet use had severe trauma $(p \leq 0.000)$.

\section{Resumo}

Objetivo: Relacionar o uso do capacete à gravidade dos traumatismos crâniocerebrais em motociclistas acidentados atendidos em hospital de trauma.

Métodos: Estudo transversal, retrospectivo. A população foi constituída de 188 registros de atendimento a motociclistas acidentados no período de quatro meses. Para caracterizar a gravidade do trauma foi utilizada a Escala de Coma de Glasgow.

Resultados: Perfil: 84,6\% sexo masculino, sendo 55,3\% entre 18 e 29 anos. Quanto ao uso de capacete no momento do acidente: 51,6\% usavam; 6,4\% não usavam; 17,6\% usaram inadequadamente; $24,5 \%$ não ocorreram registros. Dos $51,6 \%$ de motociclistas que utilizavam o equipamento de proteção, $86,6 \%$ apresentaram Traumatismos Craniocerebrais leve; 12,4\% moderado; e 1\% grave. Os traumatismos graves ocorreram mais nos motociclistas em que não havia registro sobre 0 uso do capacete.

Conclusão: Os motociclistas que utilizaram o capacete apresentaram trauma crâniocerebral leve em 44,7\%, moderado em $6,4 \%$ e grave em $0,5 \%$. As vítimas sem registro da situação do uso do capacete tiveram traumatismos graves $(p \leq 0,000)$.

${ }^{1}$ Universidade Luterana do Brasil, Canoas, RS, Brazil.

2Universidade Federal de Ciências da Saúde de Porto Alegre, RS, Brazil.

Conflicts of interest: no conflicts of interest to declare. 


\section{Introduction}

In recent years, the economic stability in Brazil enabled the growth of various sectors producing consumer goods, with a $250 \%$ increase in the automotive, motorcycle and truck market. ${ }^{(1)}$ In this context of expansion, the increase in the production of cars and motorcycles is found not only in Brazil but worldwide. ${ }^{(2-5)}$

The use of motorcycle as a means of transportation and labor is a phenomenon caused by the easiness in purchasing and maintaining it, combined with its agility, what explains the growth of sales in this market. ${ }^{(6)}$ The increasing number of vehicles, especially motorcycles, traveling in cities and highways of the country brought negative consequences, as increased occurrences and a large number of accident victims. ${ }^{(2,7)}$

The Brazilian traffic is one of the most dangerous in the world, with an accident for every 410 vehicles in circulation, while in Sweden the ratio is $1 / 21,400$ vehicles. These numbers reflect a problem of serious consequences for society, considering the morbidity, such as partial or total disability, in addition to result in high costs. ${ }^{(8)}$ Traffic accidents cost the public coffers around $\mathrm{R} \$ 28$ million per year, not counting the indirect costs. ${ }^{(1,3)}$

Accidents that victimize motorcyclists are a public health problem of great magnitude and transcendence, with strong impact on morbidity and mortality of the population. On the set of injuries from external causes, the craniocerebral trauma stands out in terms of magnitude, especially as a cause of death and disability particularly for productive young people. . $^{(2,9)}$

The initial evaluation of patients who are victims of craniocerebral trauma includes the Glasgow Coma Scale, data related to the accident and computerized tomography. This scale determines the severity of craniocerebral trauma by quantifying the neurologic findings that result from the score sum of the eye opening assessment, verbal response and motor response, evaluating the depth and clinical duration of unconsciousness and coma. ${ }^{(10)}$

The use of safety equipment, especially the helmet, is an important factor to alleviate the implications resultant of a motorcycle accident, which is observed when the victim receives emergency care. Hence, the correct use of this protection item is essential. The helmet aims to cushion the shock from the impact. ${ }^{(11)}$

In a motorcycle collision, the riders are thrown from the vehicle. The movement of their heads forward is interrupted when hitting an obstacle, but the brain continues until hitting the inside of the skull and then bounces back, reaching the opposite side, which may result in a minor or fatal injury. ${ }^{(11)}$ Motorcyclists who do not wear helmets are at a much higher risk of traumatic injuries in the head and brain, or a combination of them. Helmets create an additional protective layer for the head by protecting users from some of the most severe forms of traumatic brain injury. ${ }^{(11)}$ Therefore, victims of motorcycle accidents suffer fewer injuries with the use of protective helmets, reducing the risk of injuries in the head by two thirds, and by half in the cervical spine. ${ }^{(3)}$

The leading cause of death among users of motorcycles and bicycles are injuries to the head and neck. In European countries, head injuries contribute with roughly $75 \%$ of deaths among users of motorized two-wheelers; in some countries of low and middle-income, it is estimated that head injuries are responsible for $88 \%$ of deaths. Fractures of the nose, jaw, sinking of the face and skull, and injuries to the eye and dental arch are among the most common occurrences. ${ }^{(11)}$

Given this context, arose the interest in investigating the issue: Is the severity of craniocerebral trauma related with the helmet use in motorcycle accidents? In order to answer the question of research was defined the objective of correlating the helmet use with the severity of craniocerebral trauma, by using the Glasgow Coma Scale in injured motorcyclists treated at a trauma hospital.

\section{Methods}

This is a quantitative retrospective cross-sectional study carried out in the emergency room of a trau- 
ma hospital located in Porto Alegre / RS, Brazil. This institution is a reference in trauma in the north region of the city, and part of the Unified Health System (SUS - Sistema Único de Saúde).

The population consisted of records of patients victims of motorcycle accidents treated at the hospital emergency room with a diagnosis of craniocerebral trauma, between 01/10/2012 and $31 / 01 / 2013$. The sample considered all the patients admitted in the emergency hospital during the study period defined for the survey. Inclusion criteria were records of patients injured by motorcycle with a medical diagnosis of craniocerebral trauma, regardless if there were records on helmet use. In this service, an average of 200 victims of motorcycle accidents are assisted every month, of which $25 \%$ have craniocerebral trauma. There was no need for sample size calculation, since all records of patients who entered the hospital because of a motorcycle accident with craniocerebral trauma in the study period were selected (100\%), resulting in 188 records. A spreadsheet in Excel was elaborated as a tool for data collection with the following variables: age, gender, helmet use, severity of craniocerebral trauma and position occupied in the vehicle.

The Statistical Package for the Social Sciences version 13.0 was used for analysis of the collected data. Data were analyzed using tables and simple percentages. The Fisher's exact test was used for the verification of significant association between the variables. In the analysis of results, the maximum level of significance assumed was $5 \%(\mathrm{p} \leq 0.05)$.

The development of the study met national and international standards of ethics in research involving human beings.

\section{Results}

In relation to the profile of the sample, $84.6 \%$ of the 188 patients were male, and $55.3 \%$ were aged between 18 and 28 years.

Regarding the use of helmet, in $51.6 \%$ of the sample there were records of helmet use; in $17.6 \%$, there were records of inappropriate use because the equipment fell off at the time of the accident; and in $6.4 \%$, the helmet was not used. It is noteworthy that in $24.5 \%$ of cases there was no record whether the equipment was used or not.

The distribution of victims of motorcycle accidents with craniocerebral trauma in relation to helmet use and the variables age, gender, position of the motorcyclist, site of trauma, and injury severity are presented in table 1 .

It is observed that the age group between 18 and 28 years accounted for most of the victims who lost the equipment during the crash.

The 188 victims suffered 277 traumas to the head region, corresponding to more than one trauma per patient. They all had head trauma, as well as trauma to the jaw, face and neck. Eye and dental trauma also occurred, though less frequently. The lesions on the face can be associated with no use of protective equipment or improper use. There was also the occurrence of nose and jaw trauma in victims who were using the helmet. The trauma to the jaw was more frequently observed in victims who used the helmet improperly. Trauma to the face and neck were more common in victims with no records of protective equipment use.

Through the results of the Fisher's exact test, it was found a significant association of helmet use with the Glasgow variable. For this variable, it was observed that patients wearing helmets were associated with the mild rating (13-15 points); those in which helmet use was considered inappropriate were associated with the moderate score (9-12 points); and the severe rating (3-8 points) was associated with those in which there was no record of helmet use $(\mathrm{p} \leq 0.000)$.

Table 2 presents the victims of motorcycle accidents with craniocerebral trauma in relation to the severity of trauma assessed by the Glasgow Coma Scale with the following variables: month, age, gender, position, and site of trauma.

Regarding the severity of craniocerebral trauma suffered by the victims, 141 (50.9\%) were classified as mild; 40 (14.4\%) as moderate; and seven (2.5\%) as severe. The predominant age group of victims 
Table 1. Distribution of victims of motorcycle accidents with craniocerebral trauma in relation to helmet use

\begin{tabular}{|c|c|c|c|c|c|c|}
\hline \multirow{3}{*}{ Variables } & \multirow{3}{*}{ Category } & \multicolumn{2}{|c|}{ Helmet use } & \multicolumn{2}{|c|}{ Helmet use } & \multirow{3}{*}{$p$-value } \\
\hline & & Yes & No & Inappropriate & Not informed & \\
\hline & & $\mathrm{n}(\%)$ & $\mathrm{n}(\%)$ & $n(\%)$ & $n(\%)$ & \\
\hline \multirow[t]{5}{*}{ Age } & $7-17$ & $9(4.8)$ & $2(1.0)$ & $1(0.5)$ & $3(1.6)$ & $0.332^{\mathrm{NS}}$ \\
\hline & $18-28$ & 50(26.6) & 6(3.2) & $22(11.7)$ & 26(13.9) & \\
\hline & $29-39$ & $28(14.9)$ & $3(1.6)$ & $3(1.6)$ & $9(4.8)$ & \\
\hline & $40-50$ & $7(3.7)$ & $1(0.5)$ & $6(3.2)$ & 7(3.8) & \\
\hline & $51-60$ & $3(1.6)$ & -- & $1(0.5)$ & $1(0.5)$ & \\
\hline \multirow[t]{2}{*}{ Gender } & Male & $82(43.6)$ & $9(4.8)$ & $30(16.0)$ & 38(20.2) & $0.554^{\text {NS }}$ \\
\hline & Female & $15(8)$ & $3(1.6)$ & $3(1.6)$ & $8(4.2)$ & \\
\hline \multirow[t]{2}{*}{ Position } & Driver & 82(43.6) & $11(5.9)$ & 30(16) & 33(17.5) & $0.118^{\mathrm{NS}}$ \\
\hline & Backseat & $15(8)$ & $1(0.5)$ & $3(1.6)$ & $13(6.9)$ & \\
\hline \multirow[t]{7}{*}{ Trauma } & Skull & $97(35.0)$ & $12(4.3)$ & 33(11.9) & 46(16.6) & $N / A$ \\
\hline & Eye & $3(1.1)$ & $2(0.7)$ & $2(0.7)$ & $3(1.1)$ & \\
\hline & Nose & $9(3.2)$ & $1(0.4)$ & $3(1.1)$ & $3(1.1)$ & \\
\hline & Jaw & $10(3.6)$ & $3(1.1)$ & $6(2.2)$ & $4(1.4)$ & \\
\hline & Face & $4(1.4)$ & $2(0.7)$ & $3(1.1)$ & $8(2.8)$ & \\
\hline & Dental & $3(1.1)$ & $3(1.1)$ & $1(0.4)$ & $2(0.8)$ & \\
\hline & Neck & $5(1.8)$ & -- & $3(1.1)$ & $6(2.2)$ & \\
\hline \multirow[t]{3}{*}{ GLASGOW } & Mild & $84(44.7)$ & 6(3.3) & $14(7.4)$ & $37(19.7)$ & $0.000^{*}$ \\
\hline & Moderate & $12(6.4)$ & $5(2.7)$ & 18(9.5) & $5(2.7)$ & \\
\hline & Severe & $1(0.5)$ & $1(0.5)$ & $1(0.5)$ & $4(2.1)$ & \\
\hline
\end{tabular}

NS - not significant; N/A - Not applicable as this is a multiple answer variable

Table 2. Distribution of victims of motorcycle accidents in relation to the severity of craniocerebral trauma by the Glasgow Coma Scale

\begin{tabular}{|c|c|c|c|c|c|}
\hline \multirow{3}{*}{ Variables } & \multirow{3}{*}{ Category } & \multicolumn{3}{|c|}{ Glasgow } & \multirow{3}{*}{$p$-value } \\
\hline & & Mild & Moderate & Severe & \\
\hline & & $\mathrm{n}(\%)$ & $\mathrm{n}(\%)$ & $\mathrm{n}(\%)$ & \\
\hline \multirow[t]{5}{*}{ Age } & $7-17$ & $13(6.9)$ & $2(1.1)$ & -- & $0,550^{\mathrm{NS}}$ \\
\hline & $18-28$ & $76(40.1)$ & $23(12.2)$ & $5(2.7)$ & \\
\hline & $29-39$ & $35(18.6)$ & $7(3.7)$ & $5(2.7)$ & \\
\hline & $40-50$ & $15(8.0)$ & $5(2.7)$ & $1(0.5)$ & \\
\hline & $51-60$ & $2(1.1)$ & $3(1.6)$ & $1(0.5)$ & \\
\hline \multirow[t]{2}{*}{ Gender } & Male & 119(63.3) & $33(17.5)$ & -- & $0,723^{\mathrm{NS}}$ \\
\hline & Female & $22(11.7)$ & $7(3.7)$ & $7(3.7)$ & \\
\hline \multirow[t]{2}{*}{ Position } & Driver & $114(60.6)$ & $35(18.6)$ & -- & $0,39 g^{\text {NS }}$ \\
\hline & Backseat & $27(14.4)$ & $5(2.7)$ & & \\
\hline \multirow[t]{7}{*}{ Trauma } & Skull & $141(50.9)$ & $40(14.4)$ & $7(2.5)$ & $\mathrm{N} / \mathrm{A}$ \\
\hline & Eye & $7(2.5)$ & $2(0.8)$ & $1(0.4)$ & \\
\hline & Nose & $15(5.4)$ & -- & -- & \\
\hline & Jaw & $13(4.7)$ & $9(3.2)$ & -- & \\
\hline & Face & $16(5.8)$ & $1(0.4)$ & -- & \\
\hline & Dental & $3(1.1)$ & $3(1.1)$ & -- & \\
\hline & Neck & $15(5.4)$ & $2(0.8)$ & -- & \\
\hline
\end{tabular}

NS - not significant; N/A - Not applicable as this is a multiple answer variable

with mild, moderate and severe trauma was also be- Discussion

tween 18 and 28 years.

In relation to the position in the vehicle, it was found that $83 \%$ of victims were drivers and $17 \%$ were in the backseat. In total, were identified 21 victims of mandibular fractures (11\%) among drivers; 15 with face trauma (8\%); 14 with nose trauma $(7 \%)$, followed by neck trauma in $13(7 \%)$, denoting the inappropriate use of protective equipment.
Although the results of this research are limited by a small sample, not comprehensive of an annual assessment, data are considered to be representative of the studied phenomenon, contributing to the clarification of the issue, and pointing out evidence to confirm results of other researches. Nurses participate in health care from primary to tertiary levels. 
The results support the planning and development of preventive and recovery actions for the nursing practice and may result in decreased morbidity and mortality. When the accident occurs, nurses provide care in all stages, engaging from pre-hospital care to rehabilitation. Therefore, with more evidences, the actions both on prevention and care to victims will be better, since motorcyclists have the second highest rate of hospitalization due to traffic accidents, second only to pedestrians. ${ }^{(12)}$

A surprising aspect of this research refers to the fact that although in Brazil the legal minimum age for obtaining a motorcycle license is 18 years, five of the drivers were aged between 16 and 17 years. ${ }^{(13)}$

The profile of the study sample was of $84.6 \%$ male, mostly aged between 18 and 28 years, which is in line with other studies showing high rates of accidents involving male motorcyclists, ${ }^{(4,5,14,15)}$ and their involvement in traffic accidents for being drivers of vehicles in possession of a license, who have learned to drive when underage. ${ }^{(16)}$ The age between 18 and 28 years is primarily related with driving permission, making this a high-risk population by the inexperience in driving, the impulsive characteristic of the age, and other factors such as consumption of alcohol and other drugs, together with poor supervision by the State. ${ }^{(15)}$ A study carried out in the city of Fortaleza-CE with victims of motorcycle accidents had similar results, with predominance of the male gender, and age range between 18 and 29 years. Youngsters are more frequent victims because they present certain sociocultural behaviors, assuming greater risk in driving. ${ }^{(15)}$

When relating the variables investigated in this study, a more significant relationship between helmet use and the classification of craniocerebral trauma became evident. The majority of victims (51.6\%) which used the equipment effectively was affected by less severe trauma, presenting the following craniocerebral trauma classification, according to the Glasgow Coma Scale: $44.7 \%$ mild, $6.4 \%$ moderate and $0.5 \%$ severe. In cases where the victim used the helmet inappropriately, the traumas were on average $10.7 \%$ mild, $12.2 \%$ moderate and $1 \%$ severe, observing the double of moderate and severe trauma percentages in these victims. The
Glasgow severe classification was higher in those victims in which there was no recording of information on helmet use at the time of the accident. The omission of information about the use of the helmet at the accident site is supposedly related to future legal barriers arising from the record of nonuse of protective equipment.

A study carried out in Australia ${ }^{(17)}$ found a reduction of $66 \%$ in the probability of intracerebral lesions for motorcyclists and cyclists who wore helmets. In another study conducted in Taiwan, ${ }^{(18)}$ motorcyclists without helmets were more than four times more likely to suffer head injuries, and ten times more prone to brain damage.

A study carried out in the state of Pernambuco, in Brazil, showed that the head/neck were the second most affected body part in motorcycle drivers treated in the emergency room after the accident, while the effective use of helmet significantly reduced the severity of these lesions. ${ }^{(14,19)}$ In another study, in the state of Rio Grande do Norte (also in Brazil), it was found that motorcycles were responsible for $53.2 \%$ of the accidents, with $38.8 \%$ of motorcyclists with mild and moderate lesions, and $83.2 \%$ with mild trauma. ${ }^{(20)}$ These data corroborate the numbers found in this study and emphasize the importance of using protective equipment for preventing lesions of greater severity.

Researchers in Michigan, United States, studied the impact of helmet use on motorcycles drivers with hospital costs. Despite the mandatory helmet use in this state, $19 \%$ of drivers were not using at the time of collision. Bikers without helmets suffered more injuries in the head and neck, and had the highest rates of serious injury. ${ }^{(1)}$ In this study, $51.6 \%$ were using the equipment and $83 \%$ were motorcycle drivers. In a Brazilian study carried out in Pernambuco, $80.1 \%$ were using the helmet; ${ }^{(14)}$ half the drivers in Kenya, and 20\% of the backseat passengers wore helmets; ${ }^{(5)}$ in Jamaica $49.9 \%$ were wearing helmets at the time of the accident. ${ }^{(4)}$ As Brazil is a country with great cultural differences, it is observed that the percentages found in the present study, carried out in a city in the southern region, were different from the percentages found 
in another study held in the northeast region; the rates found in this study are more similar to numbers found in Kenya and Jamaica.

In this research, in addition to patients presenting craniocerebral trauma, 89 associated injuries also occurred: eye, nose, jaw, face, dental and neck, and the victims who were not wearing a helmet, or lost it, had two or more traumas. The mandatory and proper use of the safety device (helmet) by motorcyclists contributes with lower incidence of soft tissue injuries and fractures of the face, ${ }^{(14,20)}$ which was confirmed in this study.

Failure to use helmet or its improper use constitute an illegal act, since from 1982, helmet use became mandatory according to the Brazilian legislation. The Article 244 of the Brazilian Traffic Code, considers the nonuse of helmet a very serious offense, with penalties such as fines and suspension of driving rights, and as an administrative measure, the retention of the National Driver's License (CNH - Carteira Nacional de Habilitação). ${ }^{(13)}$ Safety equipment such as helmets are not often used by motorcyclists, making education and supervision measures necessary. ${ }^{(12)}$

\section{Conclusion}

This study allowed relating the helmet use with the severity of craniocerebral trauma of injured motorcyclists who received care at a reference center in trauma. The results showed $51.6 \%$ of motorcyclists wore helmets at the time of accident. There was a significant association between the Glasgow Coma Scale evaluation and the severity of craniocerebral trauma, showing that among bikers who correctly used the helmet $44.7 \%$ had mild trauma, $6.4 \%$ had moderate and severe trauma occurred in $0.5 \%$. Victims without records of use/nonuse of helmet had severe trauma $(\mathrm{p} \leq 0,000)$.

The highest prevalence occurred among males, aged between 18 and 28 years, and who occupied the position of motorcycle drivers.

It is necessary to expand educational strategies associated with effective public policies and more rigorous supervision of helmet use, in order to reduce the high rates of accidents involving motorcyclists without helmet use, since all studies show its effectiveness by attenuating the severity of injuries. It is also important to raise awareness of health professionals in relation to recording the use of helmet at the time of pre-hospital care.

\section{Acknowledgements}

We thank the institutional support received for the study.

\section{Collaborations}

Dutra VC; Caregnato RCA; Figueiredo MRB and Schneider DS declare to have contributed to the project design or analysis and interpretation of data; in drafting the article or critical revision of the relevant intellectual content; and final approval of the version to be published.

\section{References}

1. Departamento Nacional de Trânsito. Frota de veículos [Internet]. [citado 2013 Abr 20]. Disponível em: www.denatran.gov.br/frota.htm.

2. Carrasco CE, Godinho M, Barros MB, Rizoli S, Fraga GP. Fatal motorcycle crashes: a serious public health problem in Brazil. World J Emerg Surg. 2012; 7(Suppl 1):S5.

3. Philip AF, Fangman W, Liao J, Lilienthal M, Choi K. Helmets prevent motorcycle injuries with significant economic benefits. Traffic Inj Prev. 2013; 14(5):496-500.

4. Crandon IW, Harding HE, Cawich SO, McDonald AH, Fearron-Boothe D. Motorcycle accident injury profiles in Jamaica: an audit from the University Hospital of the West Indies. Int J Inj Contr Saf Promot. 2009 Sep; 16(3):175-8.

5. Saidi H, Mutisto B. Motorcycle injuries at a tertiary referral hospital in kenya: injury patterns and outcome. Eur J Trauma Emerg Surg. 2013; 39(5):481-5.

6. Silva DW, Soares DA, Andrade SM. [Professional performance of motorcyclists and factors associated to the traffic accidents occurrence in Londrina-PR]. Epidemiol Servi Saúde. 2008; 17(2):1357. Portuguese.

7. Silva DW, Andrade SM, Soares DA, Soares DP, Mathias TA. [Work profile and traffic accidents among motorcycle couriers in two mediumsized cities in the State of Paraná, Brazil]. Cad Saúde Pública. 2008; 24(11):2643-52. Portuguese.

8. Marín L, Queiroz MS. [Car accidents in the age of speed: an overview]. Cad Saúde Pública. 2000; 16(1):7-21. Portuguese.

9. Feitosa MS, FariaAL, Figueira MS, Nakamiti MC, Santos TC. Traumatismo cranioencefálico: morbidade e a mortalidade [Internet]. Paraíba: 
Univap; 2011 [citado 2013 Abr. 10]. Disponível em: http://www. inicepg.univap.br/cdINIC_2011/anais/arquivos/0003_0208_01.pdf.

10. Settervall $\mathrm{CH}$, Souza RM, Silva SC. [In-hospital mortality and the Glasgow Coma Scale in the first 72 hours after traumatic brain injury]. Rev Latinoam Enferm. 2011; 19(6):1337-43. Portuguese.

11. Organização Pan-Americana da Saude. Capacetes: manual de segurança no transito para os gestores e profissionais de saúde [Internet]. Organização Pan-Americana da Saude; Organização Mundial da Saude; 2007. [citado 2013 Mai 10]. Disponível em: whqlibdoc.who. int/publications/2006/9241562994_por.pdf.

12. Tavares-Filho R, Souza JN, Brasileiro ME. [Motorcycle accidents: Nursing carein emergency situations]. Rev Eletr Enferm Cent Est Enferm Nutrição. 2012; 3(3):1-20. Portuguese.

13. Brasil. Código de Trânsito Brasileiro. Instituído pela Lei nº 9.503, de 23 de setembro de 1997 [Internet]. Brasília: Denatran; 2008 [citado 2013 Abr. 20]. Disponível em: http://www.denatran.gov.br/publicacoes/ download/ctb_e_legislacao_complementar.pdf.

14. Cavalcante JR, Oka CS, de Santana Santos T, Dourado E, de Oliveira E Silva ED, Gomes AC. Influence of helmet use in facial trauma and moderate traumatic brain injury victims of motorcycle accidents. J Cranifac Surg. 2012; 23(4): 982-5.
15. Andrade LM, Lima MA, Silva CH, Caetano JA. [Motorcycle accidents: characteristics of the victims and accidents at a hospital in Fortaleza - CE, Brazil]. Rev Rene. 2009;10(4):52-9. Portuguese.

16. Santos AM, Moura ME, Nunes BM, Leal CF, Teles JB. [Profile of motorcycle accident victims treated at a public hospital emergency department]. Cad Saúde Pública. 2008; 24(8):1927-38. Portuguese.

17. McIntosh AS, Curtis K, Rankin T, Cox M, Pang, TY, McCrory P, Finch CF. Associations between helmet use and brain injuries amongst injured pedal - and motor-cyclists: A case series analysis of trauma centre presentations. J Australas Col Road Safety. 2013; 24(2):11-20.

18. Yu WY, Chen CY, Chiu WT, Lin MR. Effectiveness of different types of motorcycle helmets and effects of their improper use on head injuries. Int J Epidemiol. 2011; 40(3):794-803

19. Farias GM, Barros WC, Rocha KM, Freitas MC, Costas IK, Morais Filho LA. Farias GM, Barros WC, Rocha KM, Freitas MC, Costas IK, Morais Filho LA. Characterization of motorcycle drivers involved in traffic accidents attented at urgency hospital. J Nurs UFPE. 2009; 3(4):898907. Portuguese.

20. Ramos CS. Caracterização do acidente de trânsito e gravidade do trauma: um estudo em vítimas de um Hospital de Urgência em Natal-RN [tese]. Rio Grande do Norte: Universidade Federal do Rio Grande do Norte; 2008. 